Biological and Clinical Sciences Research Journal

ISSN: 2708-2261

www.bcsrj.com

DOI: https://doi.org/10.54112/bcsrj.v2021i1.72

Biol. Clin. Sci. Res. J., Volume, 2020: 72

MEDEYE

Review Article

\title{
GENETIC FACTORS ASSOCIATED WITH MUTATIONS OF MOLECULAR MECHANISM AND DRUG RESISTANCE IN MYCOBACTERIUM TUBERCULOSIS
}

\author{
*ARIF F, TAHIR T, SUHAIL S, ANEES R, NADEEM I, HAFEEZ MM \\ Institute of Molecular Biology and Biotechnology, The University of Lahore, Lahore, Pakistan \\ *All authors contributed equally \\ *Corresponding author email address: faryalarif433@gmail.com
}

(Received, $17^{\text {th }}$ January 2020, Revised $16^{\text {th }}$ June 2021, Published $20^{\text {th }}$ June 2021)

\begin{abstract}
Mycobacterium tuberculosis shows drug resistance patterns (drug-resistance tuberculosis DR-TB) for strains that are induced with high mortality rates. Because this acid-fast bacterium resists extensively against drugs and masks their effects to control the disease. However, these chromosomal mutations and genetic factors lead towards recent anti-TB drug discoveries. Anti-TB regimens are dearth to control this pandemic problem due to the high prevalence of this disease. These situations are remarkably given new ray to discover newer drugs that target such bacilli strains genetic factors and mutations. Also, it provides molecular updates to the resistance mechanism of mutations and genetic factors as a basic target then screened-out recent new anti-TB agents to limit the MDR-TB.
\end{abstract}

Keywords: Mycobacterium tuberculosis, drug, anti-TB agents, genetic factors, mutations

\section{Introduction}

Mycobacterium tuberculosis (Mtb) exhibits multidrug resistance against antibiotics. About one-third population of world seriously infected by very calamitous parasitic agent Mtb. World Health Organization WHO recorded that 8-10 million cases every year reported of new TB (Grobusch and Kapata, 2018; Takate et al., 2019). Mtb shows worldwide first-line drug resistant, second-line drug resistant, multi-drug resistant called (MDR), extensive drug-resistant called (XDR), extremely drug-resistant called (XXDR) and totally drugresistant called (TDR) in sequence. Mtb strains show drug resistance against

First-line drugs (Pyrazinadine/ Streptomycin/ Isoniazid/RIF)-3.9\% cases per year of RIF resistant (Takate et al., 2019). Second-line drugs (ETHCAP/MXF/KAN) and Directly Observed Treatment Short (DOTS). First, second line drugs resistance and DOTS ineffectiveness significantly leads to arise the MDR (480,000 cases per year), XDR (9.5\% cases from 17 countries per year)(Takate et al., 2019), XXDR and TDR. It induces the great challenge towards control treatment to disease (Zhang et al., 2015). In survey to Mtb in 2015 recorded $60 \%$ cases were from Pakistan, China, India, Nigeria, South Africa and Indonesia (Granich,
2018). There is not only problem about TB but also it leads the induction of co-infection (in immunecompromised persons) such as TB-HIV means that a person faces both bacterial and viral infections. It creates very serious condition to MDR-TB control, hence in 2005 WHO reported approximately 0.4 million people mortality ratio due to co-infection of TB-HIV (Padayatchi et al., 2017). It has been reported that stepwise drugs discoveries happened such as after 1944, STR or streptomycin (called a first-line of drug) discovered for TB treatment which is anti-TB drug. In drug development there were many drugs sequentially introduced but recently showed that all single called mono and cumulative therapies (which includes DOTS and DOTS plus) are not efficiently working against MDR-TB patients (Koul et al., 2011; Zhang et al., 2015).Hence now it is reported that TB become one of the challenging infectious disease globally. Genetic mutations are vigorously strong enough to induce MDR-TB in new combinatorial therapies, it is proved by that $50-70 \%$ cases by these combinatorial therapies but now they become ineffective. TB is bacterial disease it become very worst because anti-TB treatment vastly adopt to resistance against any new recent therapeutic agent, although it is slow expensive and time taking treatment of anti-TB agent (Koul et al., 2011). Resistant anti-TB agents show that there's need to

[Citation: Arif, F., Tahir, T., Suhail, S., Anees, R., Nadeem I, Hafeez, M.M., (2021). Genetic factors associated with mutations of molecular mechanism and drug resistance in Mycobacterium tuberculosis. Biol. Clin. Sci. Res. J., 2021: 72. doi: https://doi.org/10.54112/bcsrj.v2021i1.72] 
emerging advanced competitive anti-TB agents to control the disease prevalence globally. Anti-TB drugs are unable to show effectiveness against intracellular and dormant states of Mtb strains.

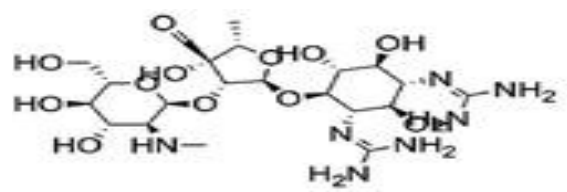

Streptomycin

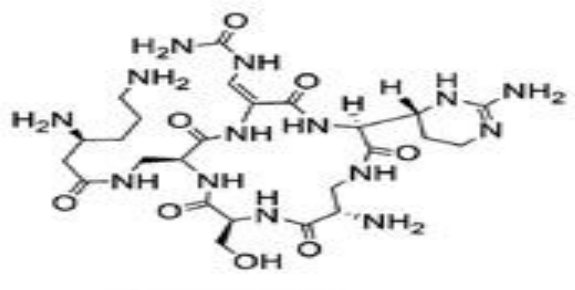

Capreomycin
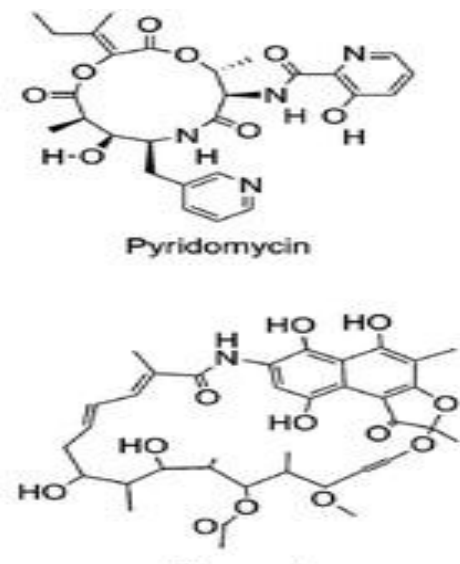

Rifamycin
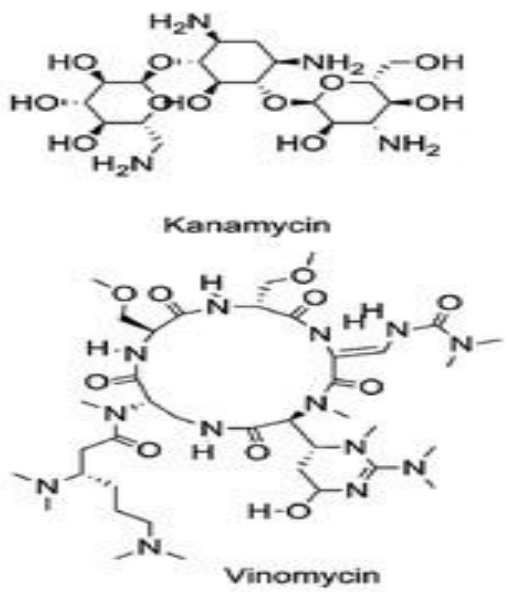

Figure 1. Anti-TB drugs that are extract from natural sources (Swain et al., 2020d)

To built the advancement in anti-TB agents which can tackle the mutational effects and stop causing the MDR. Many ways are introduced to snippet the potential compounds and chemicals of antimycobacterium agents from natural intrinsic sources.RIF and STR are included in natural drug discoveries (Figure 1)(Liu et al., 2012b; Santhosh and Suriyanarayanan, 2014; Swain et al., 2017). Natural sources are considered as parental sources for semisynthetic (RIF from rifamycin) drugs. For this challenging situation many molecular discoveries happened by drug candidates by giving chemical assays in comparison to, previous discoveries(J Sloan et al., 2013).WHO considered critical situation for this pandemic and create the slogan "Stop TB to End TB"(Mitchison and Davies, 2008b).

Mycobacterium tuberculosis mechanisms of drug resistance

Through evolutionary theory it is stated that mutations are adapted to environmental forces. Environmental conditions and long-term therapies of various combinations cause evolution in drugs to become gradually resistant strains against new emerging drugs (Figure 2). Epigenetics effects includes environmental factors that are significant cause of genetic mutations they leads to induce both ineffectiveness of new drugs as well as provide potent fit environment to Mtb strain survival also in harsh conditions (Palomino and Martin, 2014). Hence it is very dangerous situation in which epigenetic change induce such type of survival conditions for Mtb strain. It promotes MDR phenotypes and bactericidal antibiotics mutagenesis (Mitchison and Davies, 2008a; Palomino and Martin, 2014).

Immune system cells dendrite cells or alveolar macrophages (in lungs) engulf the bacterium then TB infection takes place in most cases, here bacilli consistent to reproduce by destroy the killing mechanism of host (phagocytosis, phagolysosome). Granuloma is specific site which contains complementary macrophages and other immune cells (Burian et al., 2012; Siroy et al., 2008). Mtb bacilli strains are rapidly growing in granuloma with dormant state that confer with environmental situations and create dangerous conditions of nitric oxide production, hypoxia, anorexia and nutrient deprivation (Kashyap et al., 2018).

Mycobacterium tuberculosis intrinsic resistance mechanism

Mtb strain is naturally become resistant to wide range of drugs from first-line drugs to XXDR pattern. It is very drastic situation in which natural Mtb intrinsic mechanism not confined to previously drugs that identified but also to new emerging medicines. It is divided into two types one is intrinsic and second is acquired passive neutralizing anti-TB drug regimens (Palomino and Martin, 2014).

[Citation: Arif, F., Tahir, T., Suhail, S., Anees, R., Nadeem I, Hafeez, M.M., (2021). Genetic factors associated with mutations of molecular mechanism and drug resistance in Mycobacterium tuberculosis. Biol. Clin. Sci. Res. J., 2021: 72. doi: https://doi.org/10.54112/bcsrj.v2021i1.72] 


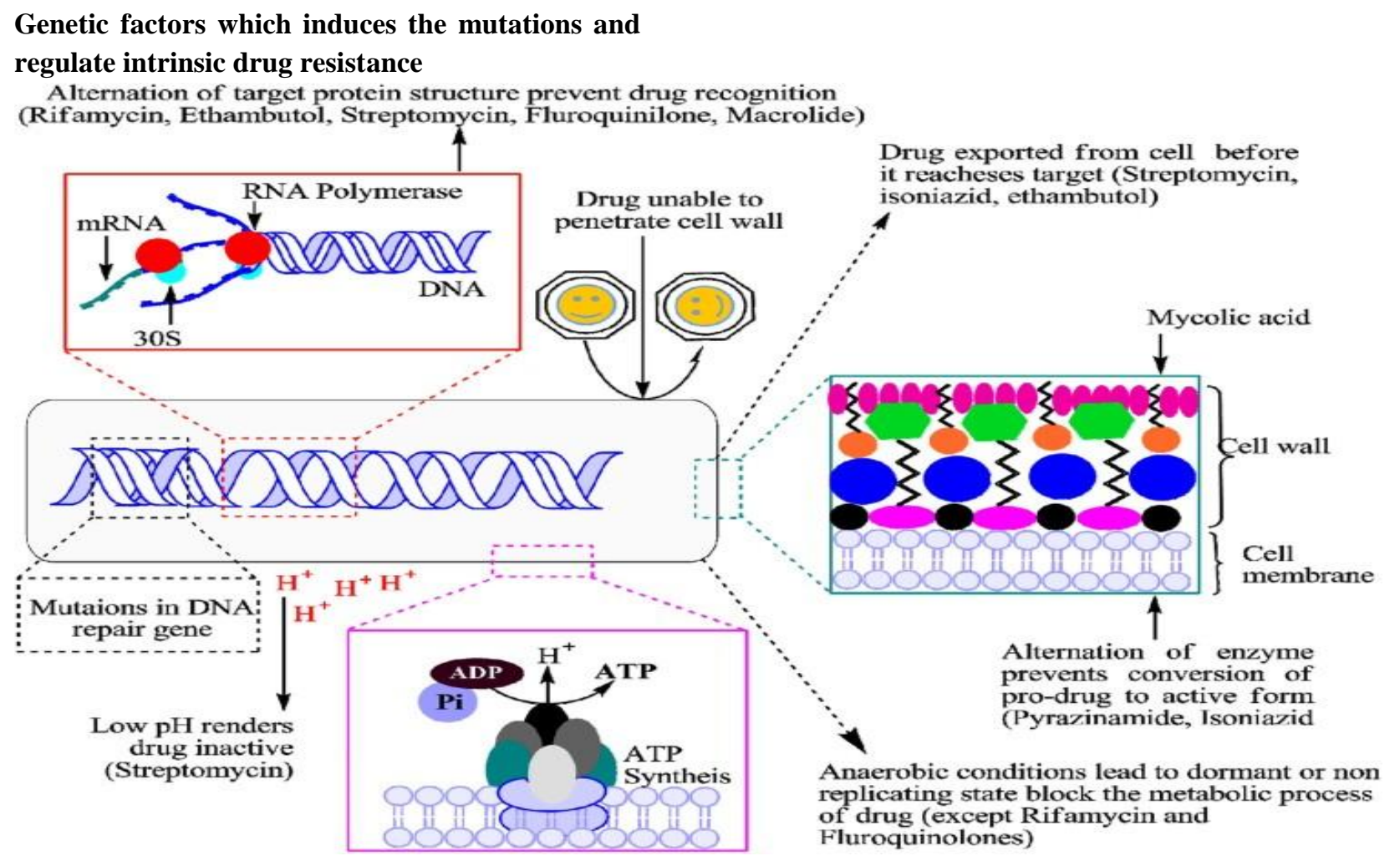

Figure 2. Mtb drug resistance mechanism by schematic view (Swain et al., 2020c)

The emr37 gene (is genetic factor which organizes binding site for 23rRNA by methylation) is attributed to cause low cell wall permeability in macrolide class of antibiotics. Mtb shows natural resistance mechanism by emr37 gene (Kashyap et al., 2018; Palomino and Martin, 2014). Clarithromycin shows eight to four fold decreased minimum inhibitory concentration (MIC) for natural mechanism od resistance in Mtb. Mtb has low permeability cell wall structure to anti-TB chemotherapy (Palomino and Martin, 2014; Viveiros et al., 2012). MspA is genetic factor in Mtb which lower drug permeability of cell wall. Mtb-Rv1698 is also gene which is related to intrinsic resistance with antimicrobial hydrophilic activities due to MspA gene (Viveiros et al., 2012). WhiB7 is called minor protein structure that contain sulfur group with 122 amino acids that are also related to redox reagents like emr37 (Burian et al., 2012).WhiB7 is auto-regulator called transcriptional activator which can manage the control of intrinsic drug resistance. It confers with tap, which is mycobacterial efflux transporter when binds to somatic sigma factor SigA against tetracycline, STR and PAS (Siroy et al., 2008; Viveiros et al., 2012). PknG is eukaryotic like protein kinase $\mathrm{G}$ is followed redox-homeostasis and a virulence factor which can allow to Mtb survive in host macrophage easily. Lsr2 which is transcription factor related to nucleoid, that regulate the level of oxygen for Mtb in macrophage by iniBAC and EfpA (efflux transport protein)(Burian et al., 2012). A significant genetic protein MarA which controls the MDR efflux pump also it lower the susceptibility of TET. Antibiotic sensitivity and redox reaction manage by $\mathrm{NADH}$ (Figure 3)(Bartek et al., 2014; Burian et al., 2012; Kashyap et al., 2018).

Many intrinsic factors of genetics which are SigA and SigF (stress responsive sigma factors)and their MarA, SoxR and Rob (transport proteins) induce resistance of anti-TB drugs(Morris et al., 2005). It is essential thing which is evaluated by bioinformatics that Mtb outer membrane proteins act with intrinsic resistance genetic factors it happens at proteomic level. Permeability barriers also related to intrinsic drug resistance by physiological adaptations (Nguyen and Pieters, 2009). By Mtb drug development a new

[Citation: Arif, F., Tahir, T., Suhail, S., Anees, R., Nadeem I, Hafeez, M.M., (2021). Genetic factors associated with mutations of molecular mechanism and drug resistance in Mycobacterium tuberculosis. Biol. Clin. Sci. Res. J., 2021: 72. doi: https://doi.org/10.54112/bcsrj.v2021i1.72] 
drugs discovered with iron containing gruesome Mtb strain which specifically targeting the intrinsic genetic factors (Lomovskaya and Bostian, 2006; Swain et al., 2020c).

Mycobacterium tuberculosis acquired resistance mechanisms

Unlike matters in different microorganism wherever non-inheritable drug resistance is usually mediate that plasmid and transposons are mobile genetic elements that are horizontally transfer by acquired drug resistance. it occurs in two different ways; 1) Chromosomal or gene mutation, 2) Extra chromosomal or gene transfer mechanism

Drug resistance is caused by impulsive mutations in body genes, manufacturing choice of resistance shear throughout the sub-optimal drug medical care. Whereas, no single pleiotropic mutation it was found that to cause associate MDR compositions in mycobacterium infectious disease, potential advanced

association between serious mutation related to resistance drug may well as associated with the starting steps within the resistance to different medications (Siroy et al., 2008). In prokaryotes, therefore the rate of mutation per replication in base pair is inversely equal to 0.0033 but in Mtb case antiTB regimens appears at 10-9 Mutations per cell division. That's why the reason anti-TB medication area unit given as mix, because the risk of mutant factor contain 2 resistance mutations is less than 1018.23 (Figure4) (Morris et al., 2005). RIF resistance in Mtb clinical isolation managed by Mutations on rpoB gene. Yet in some cases isolates have different fitness cost. i.e: less cost of fitness in vitro. Hence it depend upon Mutations that are associated with some major or minor cost of fitness strain. As a result cost of fitness depend upon genetic circumstances of the strain and specific resistance Mutation(Palomino and Martin, 2014).

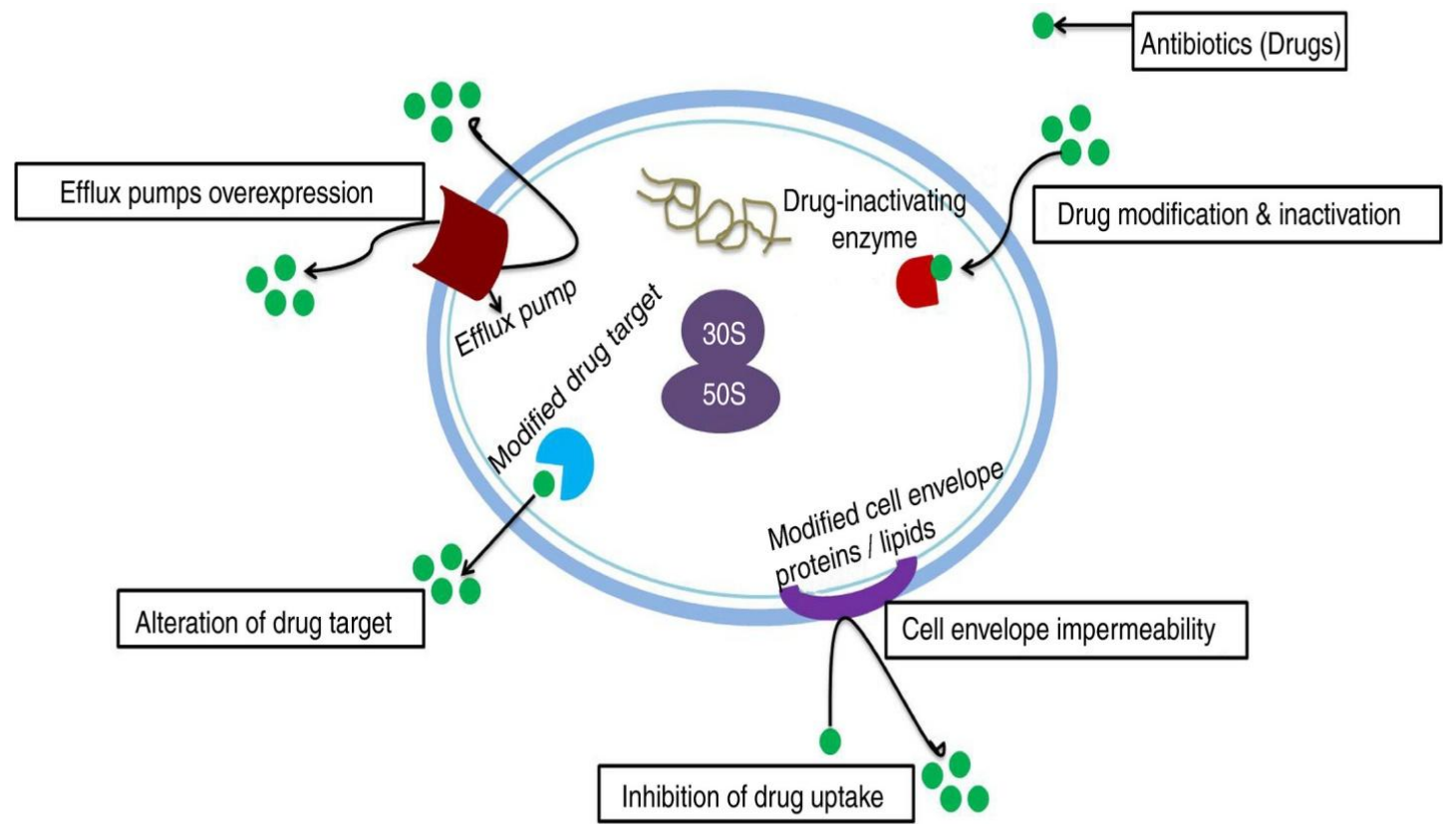

Figure 3. Efflux pumps (Swain et al., 2020c)

\section{Anti-TB medicines' drug-resistance pathways}

Due to the advent of MDR-TB as well as XDRTB strains, certain newly introduced drugs were reported to really be unreliable. In contrast to STR, the new regimens of anti-TB that are operated strains for this bacteria can never lasted on a long-term foundation (Gygli et al., 2017; Zhang and Yew, 2015). In the emergence of drug-resistant Mtb strains, environmental influences, antibiotic pressure, and chromosomal mutations all play a large part and then there's the transfer of such strains to new hosts (Morris et al., 2005).

Drugs that target cell wall, mycolic acid, and folic acid synthesis have established resistance mechanisms

Cell wall of this bacteria is made up of three covalently bound macromolecules called mycolyl-

[Citation: Arif, F., Tahir, T., Suhail, S., Anees, R., Nadeem I, Hafeez, M.M., (2021). Genetic factors associated with mutations of molecular mechanism and drug resistance in Mycobacterium tuberculosis. Biol. Clin. Sci. Res. J., 2021: 72. doi: https://doi.org/10.54112/bcsrj.v2021i1.72] 
arabinogalactan-peptidoglycan" or mAGP complex and have peptidoglycan, arabinogalactan, and mycolicacid. Myscolic acid's importance in biosynthesis appreciably established, and many drugs are produced by potentially pointing it with associated enzymes called isoniazid and EMB that were stimulate as a prodrug to inhibit biosynthesis of mycolic acid by targeting encoded enzymes inhA and katG(Almeida Da Silva and Palomino, 2011).Resistance to EMB and INH can be gained by genetic changes in the enzymes inhA and katG. Many genetic factors associated to cell wall synthesis (kasA, ndh, niA, AhpC FadE24, and FabG1) were investigated in relation to drugs of anti-TB resistance using modern molecular techniques(Timmins and Deretic, 2006). Hence same with genetic mutations in
embB and embC, which are also engaged in mycobacterium cell wall synthesis, cause resistance via Robinson transfers(Xu et al., 2015). Mutations in embB, and also mutational changes in the gene (ubiA) of decaprenyl-phosphoryl-5-phosphoribose (DPPR) synthesis, have recently been related to an increased degree of EMB resistance (Table 1-3). Resistance showing in single genetic factors pointing to cell wall drugs of anti-TB including imipenem, DCS, clofazimine, meropenem, amoxicillin and thioacetazone have been associated with poor outcomes. Folic acid biosynthesis-associated enzyme dihydropteroate synthase stimulated by the PAS and prevents regulation of iron, which is one of the most potential anti-drugs against multidrug-resistant tuberculosis since 1994 (Zhao et al., 2014).

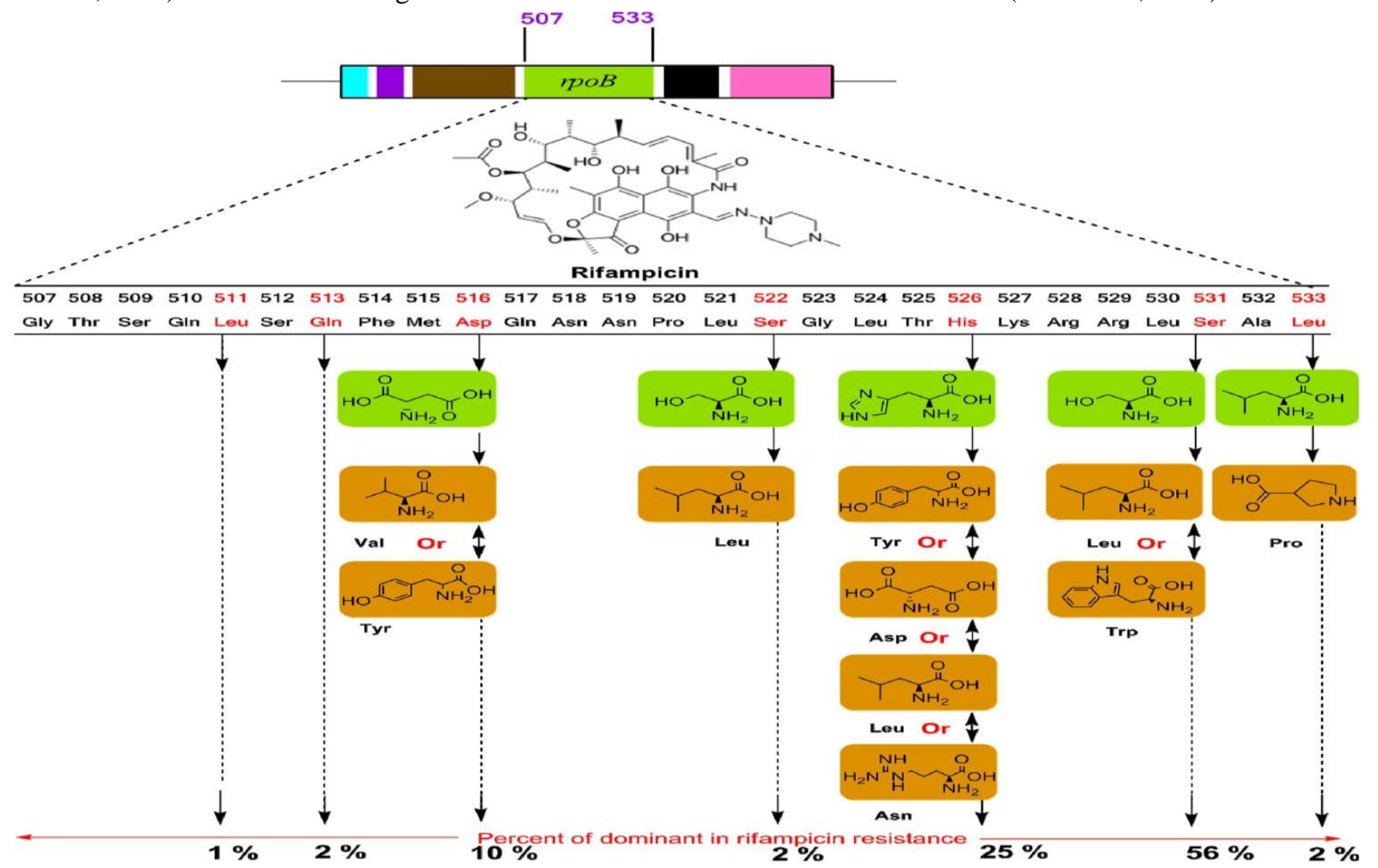

Figure 4.Genetic mutations of rifampicin target drug-resistance mechanism(Swain et al., 2020c)

For illustration, a mutation at thyA gene of Thr202Ala is found in about thirty seven percent of PAS-resistant strains of bacteria. Since from the last few years, two newly designed drugs have been more effective in suppressing Mtb cell wall synthesis ,hence resistance to these two drugs (delamanid and pretomanid) newly identified globally drugs (Mathys et al., 2009). A range of chemicals that are pointed to aminoacyl-tRNA synthetases called (AARS)associated enzymes, which are crucial for protein synthesis of bacteria (Palencia et al., 2016). Furthermore, the Mtb cell envelope comprises certain specific lipids they are the blockers of drugs to antiTB. Hence, the lipid fence is vital to the improvement

[Citation: Arif, F., Tahir, T., Suhail, S., Anees, R., Nadeem I, Hafeez, M.M., (2021). Genetic factors associated with mutations of molecular mechanism and drug resistance in Mycobacterium tuberculosis. Biol. Clin. Sci. Res. J., 2021: 72. doi: https://doi.org/10.54112/bcsrj.v2021i1.72] 
of Mtb drug resistance(Nguyen and Pieters, 2009).

The acyl-CoA carboxylases (ACC) subunits that are originated from malonyl coenzyme A (AccD1 with AccD6, AccA1 with AccA3, and AccE5) assemble different structural mycobacterium lipids. Furthermore, ACC (biotin vitamin H or B7 and called cofactor in the posttranslational procedure) is required for the preparation of mycolates, fatty acids and lipids by Mtb. As a result, inhibition of denovo biotin biosynthesis or biotin-ACC ligation acted as innovative inhibition for Mtb (Oh et al., 2006; Swain et al., 2020c; Tiwari et al., 2018).

Table 1.First-line Genetic factors related to drugs of anti TB resistance (Swain et al., 2020c)

\begin{tabular}{|c|c|c|c|c|c|c|}
\hline DRUG (year) & Chemical class & \multirow{2}{*}{\multicolumn{2}{|c|}{$\begin{array}{l}\text { Genetic factor } \\
\text { KatG,AhpC,nihA }\end{array}$}} & \multicolumn{2}{|c|}{ Resistance of medicines } & \multirow{2}{*}{$\begin{array}{l}\text { Reference } \\
\text { (Timmins and Deretic, } \\
\text { 2006) }\end{array}$} \\
\hline (1952) INH & Isonicotinic acid & & & \multicolumn{2}{|c|}{ Modification over- } & \\
\hline $\begin{array}{l}(1961) \\
\text { Ethambutol }\end{array}$ & Ethylenediamine & \multicolumn{2}{|c|}{ Emb A,embR } & \multicolumn{2}{|c|}{$\begin{array}{l}\text { expression of drug target } \\
\text { Change and over-expression } \\
\text { of drug target }\end{array}$} & \multirow{4}{*}{ 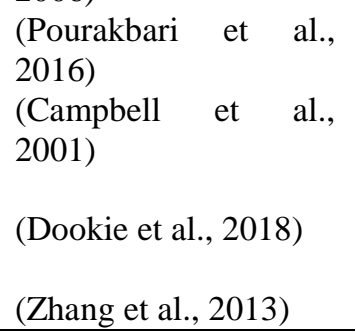 } \\
\hline $\begin{array}{l}(1963) \\
\text { Rifamnicin }\end{array}$ & Rifamycin & \multicolumn{2}{|c|}{ RpoB, FabG1 } & \multicolumn{2}{|c|}{ Modification in drug target } & \\
\hline $\begin{array}{l}\text { Rifampicin } \\
\text { (1944) }\end{array}$ & Aminoglycoside & \multicolumn{2}{|c|}{ RpsL, gidB, gpsl } & \multicolumn{2}{|c|}{ Variation in drug target } & \\
\hline $\begin{array}{l}\text { Streptomycin } \\
(1952) \\
\text { Pyrazinamide }\end{array}$ & Pyrazine & \multicolumn{2}{|c|}{ RpsA, rmLD, iniA } & \multicolumn{2}{|c|}{$\begin{array}{l}\text { Abolition } \\
\text { conversion }\end{array}$} & \\
\hline \multicolumn{7}{|c|}{ Table 2.Second-line Genetic factors of anti TB drug resistance (Swain et al., 2020c) } \\
\hline DRUG(year) & \multicolumn{2}{|c|}{ Chemical class } & \multicolumn{2}{|c|}{ Genetic factor } & & Reference \\
\hline $\begin{array}{l}\text { (1996) } \\
\text { Moxifloxacin }\end{array}$ & \multirow{2}{*}{\multicolumn{2}{|c|}{$\begin{array}{l}\text { Quinolones/8- } \\
\text { methoxyfluroquinolone } \\
\text { Serine derivative }\end{array}$}} & \multicolumn{2}{|c|}{ gyrA, gyrB } & Alternation of drug & $\begin{array}{l}\text { (Rustomjee et al., } \\
\text { 2008) }\end{array}$ \\
\hline (1955) Cycloserine & & & ddl, Aid & & $\begin{array}{l}\text { Over-expression } \\
\text { resistance gene }\end{array}$ & $\begin{array}{l}\text { (Cáceres et al., } \\
\text { 1997) }\end{array}$ \\
\hline (1956) Ethionamide & \multicolumn{2}{|c|}{ Isoconitic acid derivative } & \multicolumn{2}{|c|}{ ethA, ethR } & $\begin{array}{l}\text { Alternation and over } \\
\text { expression drug }\end{array}$ & (Lin et al., 2014) \\
\hline $\begin{array}{l}(1963) \\
\text { Capreomycin }\end{array}$ & \multicolumn{2}{|c|}{ Cyclic polypeptide } & \multicolumn{2}{|l|}{ rrs, thyA } & $\begin{array}{l}\text { Mutation alternation } \\
\text { drug }\end{array}$ & (Lin et al., 2014) \\
\hline $\begin{array}{l}\text { (1957) Kanamycin } \\
\text { (1972) Amikacin }\end{array}$ & \multicolumn{2}{|c|}{ Amino-glycosides } & \multicolumn{2}{|c|}{ Rrs,eis,whiB7 } & Mutation on $16 \mathrm{~S}$ rRNA & $\begin{array}{l}\text { (Dookie } \\
\text { 2018) }\end{array}$ \\
\hline
\end{tabular}

Table 3.Third-line Genetic factors of anti TB drug resistance (Swain et al., 2020c)

\begin{tabular}{|c|c|c|c|c|}
\hline Drug (Year) & Chemical class & Genetic factor & Drug resistance & References \\
\hline $\begin{array}{l}(1954) \\
\text { Clofazimine }\end{array}$ & $\begin{array}{l}\text { Iminophenazine } \\
\text { derivative } \\
\text { (bacteriostatic) }\end{array}$ & rv0678, rv1979c,rv2535c,ndh & $\begin{array}{l}\text { Up-regulation of efflux } \\
\text { pump, MmpL5 because of } \\
\text { mutations }\end{array}$ & $\begin{array}{l}\text { (Yano et al., } \\
\text { 2011) }\end{array}$ \\
\hline $\begin{array}{l}\text { (2012) } \\
\text { Bedaquiline }\end{array}$ & $\begin{array}{l}\text { Quinoline } \\
\text { (bactericidal/ } \\
\text { bacteriostatic) }\end{array}$ & rv0678, atpE, pepQ & $\begin{array}{l}\text { Mutational changes to co- } \\
\text { infection and binding site }\end{array}$ & $\begin{array}{l}\text { (Palomino and } \\
\text { Martin, 2013) }\end{array}$ \\
\hline $\begin{array}{l}(2014) \\
\text { Delamanid } \\
(2020)\end{array}$ & $\begin{array}{l}\text { Nitroimidazole } \\
\text { (bactericidal) }\end{array}$ & fgd1,fbiC,fbiA,fbiB,ddn & $\begin{array}{l}\text { Mutations on reductive } \\
\text { activating gene }\end{array}$ & $\begin{array}{l}\text { (Feuerriegel et } \\
\text { al., 2011) }\end{array}$ \\
\hline $\begin{array}{l}\text { Pretomanid } \\
(2000) \\
\text { Linezolid }\end{array}$ & $\begin{array}{l}\text { Oxazolidinone } \\
\text { (bactericidal) }\end{array}$ & $\mathrm{rp} 1 \mathrm{C}, \mathrm{rr} 1$ & $\begin{array}{l}\text { Mutation in 50S ribosomal } \\
\text { L3 protein }\end{array}$ & $\begin{array}{l}\text { (Richter et al., } \\
\text { 2007) }\end{array}$ \\
\hline
\end{tabular}

\footnotetext{
Drug targeting ATP, DNA, RNA and protein synthesis resistance mechanism

MTB resistance trait in the pandemic that have arisen as a result of evolution, antibiotic strain, and other factors indicate that this mutant function is necessary for his or her survival in a completely new environment. Because of a degree mutation, the used
} drug is unable to bind to the correct target sites, lowering its efficacy (Dookie et al., 2018; Morris et al., 2005). The pathways of central dogma for example Nodal enzymes, DNA, polymer and super molecule synthesis, that have been encoded associate degreed forerunner attained the specified combination for extant within a setting or even a

[Citation: Arif, F., Tahir, T., Suhail, S., Anees, R., Nadeem I, Hafeez, M.M., (2021). Genetic factors associated with mutations of molecular mechanism and drug resistance in Mycobacterium tuberculosis. Biol. Clin. Sci. Res. J., 2021: 72. doi: https://doi.org/10.54112/bcsrj.v2021i1.72] 
number body. As a result, several anti-TB drugs have been produced that target ATP, DNA and super molecule synthesis, all of which are important for Mtb survival Antibiotics/drugs in the imidazopyridine and dirylquinoline organic compound categories target Mtb's adenosine triphosphate synthesis, while PAS inhibits Mtb's DNA synthesis precursor, and antibiotics in the fluoroquinolone class inhibit Mtb's DNA gyrase (Morris et al., 2005). Polymer synthesis is inhibited by RIF, whereas macrolides, cyclic peptides, oxazolidinones (linezolid) and aminoglycosides inhibit super molecule synthesis. Linezolid, for example, is a potential orally available drug that targets Mtb super molecule synthesis. Mutated rpoB causes a conformational change in RIF's binding affinity at the subunit of the polymer enzyme, rendering the drug inactive and preventing it from binding to the specific pointing website (Kashyap et al., 2018; Morris et al., 2005). Newly introduced two medication, pretomanid and delamanid are simpler in the direction of Mtb inhibition plasma membrane arrange within the few year, Recently, drug resistance to these two medications has been recorded all over the world (Palomino and Martin, 2014).

\section{Drug Resistance and Drug Development upcoming future prospective}

Among microbes and human individuals there is a battle for persistence since long time. For this survival evolution of antibiotics helps a lot from many centuries. But contemporarily the bacteria (mycobacterium tuberculosis) creates some specific genetic factors and produce competence and bio-film formation through colony wide coordination for the purpose of retribution opposing to novel anti-TB drug (Nguyen and Pieters, 2009; Viveiros et al., 2012). From pre-existing variants strains, contemporary variants or mutants can retrieve proficiency for intensify transmission of virulence through adopting resistance mechanism with a worthy environmental pressure (Gygli et al., 2017; Lynch, 2011). In past it was suggested many MDR (multi-drug resistance) epidemics involved in the development of regulation systems through an antibiotics enhancement of phenotypic drug tolerant ability of latent TB and also convert Mtb into active growth from dormant state. According to nowadays examination TB which is drug resistant mostly compared on basis of Mtb target enzymes which lie on genetic mutations (Almeida et al., 2016; Mathys et al., 2009; Zhang et al., 2013). Variations led to resistance factors which are mostly divided into two types:

Cellular mechanism is a type in which mismatch renovations takes place like DNA polymorphisms error or like translational inaccuracy. Second type is External mechanism which is mainly interlinked to stress factors, pollutions or quality of diagnosis (Lomovskaya and Bostian, 2006). There are also some social and economic factors which are mainly involved in drug resistance of TB: Insufficient hospital facilities, Ill-suited guidance, Long lasting expenses, National antibiotic policy has lack of strictness, Lack of awareness, Illiteracy rate and Indigence (Bhatt et al., 2019).

Apart from these factors when TB patients do not cooperate and show carelessness about their disease then it's become impossible to achieve complete cure. Costs of drugs are also directly effect on cure rate. From other infectious diseases like malaria HIV and hepatitis TB is the primary disease which cause mortality rate high among adults or youngsters in Asian populations(Sizemore et al., 2012; Sotgiu et al., 2019). Co-infection is actually a type of infection which cause due to multiple pathogen species and when TB which is mostly co-infect with HIV developed than it's led to enhance strains of XDR-TB and MDR-TB strains. Because when both disease cause at the same time than its latent or active TB disease and its cause resistance against TB drugs (Kaplan et al., 2018).

Due to this co-infection of HIV and TB rate of TB infections gets high triplet times in Africa. Rate of TB infections in Africa were round about 39\%. Due to this record it seems to more difficult to treat coinfected TB. There is some anti-TB drugs which include bed aquiline pretomanid and delamanid are approved continuously and in small time period they provide best drug development performance. Still we have to be compelled to produce or develop more drugs to control TB infection through which globally millions of people died(Palomino and Martin, 2013). In medical research round about 265 billion dollars deposit for research and development of new

[Citation: Arif, F., Tahir, T., Suhail, S., Anees, R., Nadeem I, Hafeez, M.M., (2021). Genetic factors associated with mutations of molecular mechanism and drug resistance in Mycobacterium tuberculosis. Biol. Clin. Sci. Res. J., 2021: 72. doi: https://doi.org/10.54112/bcsrj.v2021i1.72] 
techniques of medication and diagnosis but from all this input only $0.25 \%$ output provided (Beena and Rawat, 2013). According to WHO (World Health Organization) report or documentary there are many agents which acts against to TB located in drugs pipeline and WHO has hope for to discover them in future. In some reports and articles, there are some agents of tubercular which contain heterocyclic nitrogen which contain pyridine and pyrazine derivatives which are similar to previously present anti-TB drugs which are pyrazinamide and Isoniazid. The presence of nucleus in nitrogen heterocyclic is beneficial for future anti-TB drug because it is a necessary chemical scaffold in which some metabolic, physiochemical and pharmacokinetic properties are present. In recent future for development of productive anti-TB (mycobacterium tuberculosis) drugs the outstanding progress carry out through screening with some techniques in molecular and mechanism of medicine. Secondary plant metabolites involved natural phyto-metabolites and cyanobacterium compound include phyco chemical are under search for to achievement of drugs of anti TB because both of compounds have special potential towards health and health problems and disease rate(J. Sloan et al., 2013; Kumar et al., 2011).

One of the classes of phyto-chemicals is terpenoid: From well Indian medicinal plant mono-O-methyl curcumin isoxazole $00019 \mathrm{mg} / \mathrm{Ml}$ is MIC value of Curcuma longa, $0.00039 \mathrm{mg} / \mathrm{Ml}$ is MIC value of Plectanthus granadidentatus, MIC values 0.0015$0.0033 \mathrm{mg} / \mathrm{mL}$ of Plumbagin from Disopyros anisandra, from South African medicinal bosket 7 methyljuglone has its MIC value $00057 \mathrm{mg}$ per $\mathrm{mL}$, from Malaysian sub-species which is organic heterocyclic compound is MIC value 0.0031$0.016 \mathrm{mg}$ per $\mathrm{mL}$ of Calophyllum lanigerum and Celastrus vulcanicola is group of alkaloid components with its MIC value $0.0062 \mathrm{mg} / \mathrm{ml}$ (Changtam et al., 2010; Lall et al., 2005; Uc-Cachón et al., 2014; Xu et al., 2004). When their talks about host-toxicity then plant chemicals are consider being ideal drugs candidates in contrast to marine chemicals but drug progress rates are high in aquatic drug products than to plants drug outcomes (Liu et al., 2012a). In purpose to be an ideal participant in drug effectiveness then participant must maintain cumulatively process of toxicity and activity with pharmacokinetic characteristics. Many medicinal chemistry procedures and synthesis of nano-particle take place in order to establish anti-TB drug development (Nasiruddin et al., 2017; Swain et al., 2020a; Swain et al., 2020b). Many factors play important role in order to sustainable TB-free society like scientific Endeavour geographical support administrative commitment and long-term investment.

\section{Conclusion}

Drug resistance of mycobacterium tuberculosis now has become serious issue globally in medical concerns. All lines of drug resistances become stronger due to lack of heavy potential drug awareness. Potential molecular mechanism of this bacterial drug resistance required rapid latest regimens of anti-TB drugs .New modified genetic sciences that are combat to this critical situation should develop these mutational modifications. Mtb gives us innovative ways to study how can certain bacteria resist all the drugs by modifying its genetics and its enable us to discover more and more potential drugs.

\section{Conflict of interest}

The authors showed absence of conflict of interest.

\section{References}

Almeida, D., Ioerger, T., Tyagi, S., Li, S.-Y., Mdluli, K., Andries, K., Grosset, J., Sacchettini, J., and Nuermberger, E. (2016). Mutations in pepQ Confer Low-Level Resistance to Bedaquiline and Clofazimine in Mycobacterium tuberculosis. Antimicrobial agents and chemotherapy, 60, 4590-4599.

Almeida Da Silva, P. E., and Palomino, J. C. (2011). Molecular basis and mechanisms of drug resistance in Mycobacterium tuberculosis: classical and new drugs. Journal of Antimicrobial Chemotherapy 66, 1417-1430.

Bartek, I. L., Woolhiser, L. K., Baughn, A. D., Basaraba, R. J., Jacobs, W. R., Lenaerts, A. J., and Voskuil, M. I. (2014). Mycobacterium tuberculosis Lsr2 is a global transcriptional regulator required for adaptation to changing oxygen levels and virulence. MBio, 5, e01106-14.

Beena, and Rawat, D. S. (2013). Antituberculosis Drug Research: A Critical Overview. 33, 693764. 
Bhatt, R., Chopra, K., and Vashisht, R. (2019). Impact of integrated psycho-socio-economic support on treatment outcome in drug resistant tuberculosis - A retrospective cohort study. Indian Journal of Tuberculosis 66, 105-110.

Burian, J., Ramón-García, S., Howes, C. G., and Thompson, C. J. (2012). WhiB7, a transcriptional activator that coordinates physiology with intrinsic drug resistance in Mycobacterium tuberculosis. Expert Review of Anti-infective Therapy 10, 1037-1047.

Cáceres, N. E., Harris, N. B., Wellehan, J. F., Feng, Z., Kapur, V., and Barletta, R. G. (1997). Overexpression of the $\mathrm{D}$-alanine racemase gene confers resistance to D-cycloserine in Mycobacterium smegmatis. 179, 5046-5055.

Campbell, E. A., Korzheva, N., Mustaev, A., Murakami, K., Nair, S., Goldfarb, A., and Darst, S. A. (2001). Structural Mechanism for Rifampicin Inhibition of Bacterial RNA Polymerase. Cell 104, 901-912.

Changtam, C., Hongmanee, P., and Suksamrarn, A. (2010). Isoxazole analogs of curcuminoids with highly potent multidrug-resistant antimycobacterial activity. European Journal of Medicinal Chemistry 45, 4446-4457.

Dookie, N., Rambaran, S., Padayatchi, N., Mahomed, S., and Naidoo, K. (2018). Evolution of drug resistance in Mycobacterium tuberculosis: a review on the molecular determinants of resistance and implications for personalized care. Journal of Antimicrobial Chemotherapy 73, 1138-1151.

Feuerriegel, S., Köser, C. U., Baù, D., Rüsch-Gerdes, S., Summers, D. K., Archer, J. A. C., MartiRenom, M. A., and Niemann, S. (2011). Impact of Fgd1 and ddn diversity in Mycobacterium tuberculosis complex on in vitro susceptibility to PA-824. Antimicrobial Agents and Chemotherapy, 55, 5718-5722.

Granich, R. J. T. L. (2018). Is the global tuberculosis control strategy too big to fail? 392, 2165.

Grobusch, M. P., and Kapata, N. J. T. L. I. D. (2018). Global burden of tuberculosis: where we are and what to do. 18, 1291-1293.

Gygli, S. M., Borrell, S., Trauner, A., and Gagneux, S. (2017). Antimicrobial resistance in Mycobacterium tuberculosis: mechanistic and evolutionary perspectives. FEMS Microbiology Reviews 41, 354-373.

Kaplan, S. R., Topal, J., Sosa, L., Malinis, M., Huttner, A., Malhotra, A., and Friedland, G. (2018). A patient with central nervous system tuberculomas and a history of disseminated multi-drug-resistant tuberculosis. Journal of Clinical Tuberculosis and Other Mycobacterial Diseases 10, 9-16.

Kashyap, A., Singh, P. K., and Silakari, O. (2018). Mechanistic investigation of resistance via drug-inactivating enzymes in Mycobacterium tuberculosis. Drug Metabolism Reviews 50, 448-465.

Koul, A., Arnoult, E., Lounis, N., Guillemont, J., and Andries, K. J. N. (2011). The challenge of new drug discovery for tuberculosis. 469, 483-490.

Kumar, K., Awasthi, D., Lee, S.-Y., Zanardi, I., Ruzsicska, B., Knudson, S., Tonge, P. J., Slayden, R. A., and Ojima, I. (2011). Novel Trisubstituted Benzimidazoles, Targeting Mtb FtsZ, as a New Class of Antitubercular Agents. Journal of Medicinal Chemistry 54, 374-381.

Lall, N., Meyer, J. J. M., Wang, Y., Bapela, N. B., van Rensburg, C. E. J., Fourie, B., and Franzblau, S. G. (2005). Characterization of Intracellular Activity of Antitubercular Constituents the Roots of Euclea natalensis. Pharmaceutical Biology 43, 353-357.

Lin, S.-Y. G., Rodwell, T. C., Victor, T. C., Rider, E. C., Pham, L., Catanzaro, A., and Desmond, E. P. (2014). Pyrosequencing for Rapid Detection of Extensively Drug-Resistant <span class="named-content genus-species" $\mathrm{id}=$ "named-content-1" $>$ Mycobacterium tuberculosis $</$ span $>$ in Clinical Isolates and Clinical Specimens. 52, 475-482.

Liu, X., Chen, C., He, W., Huang, P., Liu, M., Wang, Q., Guo, H., Bolla, K., Lu, Y., Song, F., Dai, H., Liu, M., and Zhang, L. (2012a). Exploring anti-TB leads from natural products library originated from marine microbes and medicinal plants. Antonie van Leeuwenhoek 102, 447-461.

Liu, X., Chen, C., He, W., Huang, P., Liu, M., Wang, Q., Guo, H., Bolla, K., Lu, Y., and Song, F. J. A. v. L. (2012b). Exploring anti-TB leads from natural products library originated from marine microbes and medicinal plants. 102, 447-461.

Lomovskaya, O., and Bostian, K. A. (2006). Practical applications and feasibility of efflux pump inhibitors in the clinic-A vision for applied use. Biochemical Pharmacology 71, 910-918.

Lynch, M. (2011). The Lower Bound to the Evolution of Mutation Rates. Genome Biology and Evolution 3, 1107-1118.

Mathys, V., Wintjens, R., Lefevre, P., Bertout, J., Singhal, A., Kiass, M., Kurepina, N., Wang,

[Citation: Arif, F., Tahir, T., Suhail, S., Anees, R., Nadeem I, Hafeez, M.M., (2021). Genetic factors associated with mutations of molecular mechanism and drug resistance in Mycobacterium tuberculosis. Biol. Clin. Sci. Res. J., 2021: 72. doi: https://doi.org/10.54112/bcsrj.v2021i1.72] 
X.-M., Mathema, B., Baulard, A., Kreiswirth, B. N., and Bifani, P. (2009). Molecular Genetics of <em>para</em>-Aminosalicylic Acid Resistance in Clinical Isolates and Spontaneous Mutants of <em $>$ Mycobacterium tuberculosis $</$ em $>$. 53, 2100-2109.

Mitchison, D. A., and Davies, G. R. (2008a). Assessment of the Efficacy of New AntiTuberculosis Drugs. Open Infect Dis J 2, 5976.

Mitchison, D. A., and Davies, G. R. J. T. o. i. d. j. (2008b). Assessment of the efficacy of new anti-tuberculosis drugs. 2, 59.

Morris, R. P., Nguyen, L., Gatfield, J., Visconti, K., Nguyen, K., Schnappinger, D., Ehrt, S., Liu, Y., Heifets, L., Pieters, J., Schoolnik, G., and Thompson, C. J. (2005). Ancestral antibiotic resistance in Mycobacterium tuberculosis. Proceedings of the National Academy of Sciences, 102, 12200-12205.

Nasiruddin, M., Neyaz, M. K., and Das, S. (2017). Nanotechnology-Based Approach in Tuberculosis Treatment. Tuberculosis Research and Treatment 2017, 4920209.

Nguyen, L., and Pieters, J. (2009). Mycobacterial Subversion of Chemotherapeutic Reagents and Host Defense Tactics: Challenges in Tuberculosis Drug Development. 49, 427453.

Oh, T.-J., Daniel, J., Kim, H.-J., Sirakova, T. D., and Kolattukudy, P. E. (2006). Identification and Characterization of Rv3281 as a Novel Subunit of a Biotin-dependent Acyl-CoA Carboxylase in Mycobacterium tuberculosis H37Rv. Journal of Biological Chemistry 281, 3899-3908.

Padayatchi, N., Naidu, N., Friedland, G., Naidoo, K., Conradie, F., Naidoo, K., and O'Donnell, M. R. J. I. J. o. I. D. (2017). Turning the tide against tuberculosis. 56, 6-9.

Palencia, A., Li, X., Bu, W., Choi, W., Ding, C. Z., Easom, E. E., Feng, L., Hernandez, V., Houston, P., Liu, L., Meewan, M., Mohan, M., Rock, F. L., Sexton, H., Zhang, S., Zhou, Y., Wan, B., Wang, Y., Franzblau, S. G., Woolhiser, L., Gruppo, V., Lenaerts, A. J., O'Malley, T., Parish, T., Cooper, C. B., Waters, M. G., Ma, Z., Ioerger, T. R., Sacchettini, J. C., Rullas, J., Angulo-Barturen, I., Pérez-Herrán, E., Mendoza, A., Barros, D., Cusack, S., Plattner, J. J., and Alley, M. R. K. (2016). Discovery of novel oral protein synthesis inhibitors of Mycobacterium tuberculosis that target leucyl-tRNA synthetase." Antimicrobial Agents and Chemotherapy, 60, 6271-6280.

Palomino, J. C., and Martin, A. (2013). TMC207 becomes bedaquiline, a new anti-TB drug. 8 , 1071-1080.

Palomino, J. C., and Martin, A. (2014). Drug Resistance Mechanisms in Mycobacterium tuberculosis. 3, 317-340.

Pourakbari, B., Mamishi, S., Mohammadzadeh, M., and Mahmoudi, S. (2016). First-Line AntiTubercular Drug Resistance of Mycobacterium tuberculosis in IRAN: A Systematic Review. 7.

Richter, E., Rüsch-Gerdes, S., and Hillemann, D. (2007). First linezolid-resistant clinical isolates of Mycobacterium tuberculosis. Antimicrobial agents and chemotherapy, 51, 1534-1536.

Rustomjee, R., Lienhardt, C., Kanyok, T., Davies, G. R., Levin, J., Mthiyane, T., Reddy, C., Sturm, A. W., Sirgel, F. A., Allen, J., Coleman, D. J., Fourie, B., Mitchison, D. A., and Gatifloxacin for, T. B. s. t. (2008). A Phase II study of the sterilising activities of ofloxacin, gatifloxacin and moxifloxacin in pulmonary tuberculosis. The International Journal of Tuberculosis and Lung Disease 12, 128-138.

Santhosh, R. S., and Suriyanarayanan, B. J. P. m. (2014). Plants: a source for new antimycobacterial drugs. 80, 9-21.

Siroy, A., Mailaender, C., Harder, D., Koerber, S., Wolschendorf, F., Danilchanka, O., Wang, Y., Heinz, C., and Niederweis, M. (2008). Rv1698 of Mycobacterium tuberculosis Represents a New Class of Channel-forming Outer Membrane Proteins. Journal of Biological Chemistry 283, 17827-17837.

Sizemore, C. F., Schleif, A. C., Bernstein, J. B., and Heilman, C. A. (2012). The role of biomedical research in global tuberculosis control: gaps and challenges. Emerging Microbes \& Infections 1, 1-6.

Sloan, j.D., R. Davies, G., and H. Khoo, S. (2013). New Drugs and Treatment Regimens. Current Respiratory Medicine Reviews 9, 200-210.

Sotgiu, G., Goletti, D., and Matteelli, A. (2019). Global tuberculosis prevention: should we start from the beginning? 54, 1901394.

Swain, S. S., Paidesetty, S. K., Dehury, B., Das, M., Vedithi, S. C., and Padhy, R. N. (2020a). Computer-aided synthesis of dapsonephytochemical conjugates against dapsoneresistant Mycobacterium leprae. Scientific Reports 10, 6839.

[Citation: Arif, F., Tahir, T., Suhail, S., Anees, R., Nadeem I, Hafeez, M.M., (2021). Genetic factors associated with mutations of molecular mechanism and drug resistance in Mycobacterium tuberculosis. Biol. Clin. Sci. Res. J., 2021: 72. doi: https://doi.org/10.54112/bcsrj.v2021i1.72] 
Swain, S. S., Paidesetty, S. K., Padhy, R. N., and Hussain, T. (2020b). Isoniazid-phytochemical conjugation: A new approach for potent and less toxic anti-TB drug development. 96, 714730 .

Swain, S. S., Paidesetty, S. K., Padhy, R. N., and Singh, P. K. J. I. J. P. E. R. (2017). Computational approach for locating effective cyanobacterial compounds against Mycobacterium tuberculosis. 51, 1-10.

Swain, S. S., Sharma, D., Hussain, T., and Pati, S. (2020c). Molecular mechanisms of underlying genetic factors and associated mutations for drug resistance in Mycobacterium tuberculosis. Emerging Microbes \& Infections 9, 1651-1663.

Swain, S. S., Sharma, D., Hussain, T., and Pati, S. (2020d). Molecular mechanisms of underlying genetic factors and associated mutations for drug resistance in Mycobacterium tuberculosis. Emerg Microbes Infect 9, 16511663.

Takate, S. J., Shinde, A. D., Karale, B. K., Akolkar, H., Nawale, L., Sarkar, D., Mhaske, P. C. J. B., and letters, m. c. (2019). Thiazolylpyrazole derivatives as potential antimycobacterial agents. 29, 1199-1202.

Timmins, G. S., and Deretic, V. (2006). Mechanisms of action of isoniazid. 62, 1220-1227.

Tiwari, D., Park, S. W., Essawy, M. M., Dawadi, S., Mason, A., Nandakumar, M., Zimmerman, M., Mina, M., Ho, H. P., Engelhart, C. A., Ioerger, T., Sacchettini, J. C., Rhee, K., Ehrt, S., Aldrich, C. C., Dartois, V., and Schnappinger, D. (2018). Targeting protein biotinylation enhances tuberculosis chemotherapy. 10, eaal1803.

Uc-Cachón, A. H., Borges-Argáez, R., SaidFernández, S., Vargas-Villarreal, J., GonzálezSalazar, F., Méndez-González, M., CáceresFarfán, M., and Molina-Salinas, G. M. (2014). Naphthoquinones isolated from Diospyros anisandra exhibit potent activity against panresistant first-line drugs Mycobacterium tuberculosis strains. Pulmonary Pharmacology \& Therapeutics 27, 114-120.

Viveiros, M., Martins, M., Rodrigues, L., Machado, D., Couto, I., Ainsa, J., and Amaral, L. (2012). Inhibitors of mycobacterial efflux pumps as potential boosters for anti-tubercular drugs. Expert Review of Anti-infective Therapy 10, 983-998.

Xu, Y., Jia, H., Huang, H., Sun, Z., and Zhang, Z. (2015). Mutations found in embCAB, embR, and ubiA genes of ethambutol-sensitive andresistant Mycobacterium tuberculosis clinical isolates from China. BioMed Research International 2015, 951706.

Xu, Z.-Q., Barrow, W. W., Suling, W. J., Westbrook, L., Barrow, E., Lin, Y.-M., and Flavin, M. T. (2004). Anti-HIV natural product (+)calanolide $\mathrm{A}$ is active against both drugsusceptible and drug-resistant strains of Mycobacterium tuberculosis. Bioorganic \& Medicinal Chemistry 12, 1199-1207.

Yano, T., Kassovska-Bratinova, S., Teh, J. S., Winkler, J., Sullivan, K., Isaacs, A., Schechter, N. M., and Rubin, H. (2011). Reduction of Clofazimine by Mycobacterial Type 2 NADH:Quinone Oxidoreductase: A pathway for the generation of bactericidal levels of reactive oxygen species. Journal of Biological Chemistry 286, 10276-10287.

Zhang, S., Chen, J., Shi, W., Liu, W., Zhang, W., and Zhang, Y. (2013). Mutations in panD encoding aspartate decarboxylase are associated with pyrazinamide resistance in Mycobacterium tuberculosis. Emerging Microbes \& Infections 2, 1-5.

Zhang, Y., Yew, W. J. T. I. J. o. T., and Disease, L. (2015). Mechanisms of drug resistance in Mycobacterium tuberculosis: update 2015. 19, 1276-1289.

Zhang, Y., and Yew, W. W. (2015). Mechanisms of drug resistance in Mycobacterium tuberculosis: update 2015. The International Journal of Tuberculosis and Lung Disease 19, 1276-1289.

Zhao, F., Wang, X.-D., Erber, L. N., Luo, M., Guo, A.-z., Yang, S.-s., Gu, J., Turman, B. J., Gao, Y.-r., Li, D.-f., Cui, Z.-q., Zhang, Z.-p., Bi, L.j., Baughn, A. D., Zhang, X.-E., and Deng, J.Y. (2014). Binding pocket alterations in dihydrofolate synthase confer resistance to para-aminosalicylic acid in clinical isolates of Mycobacterium tuberculosis. Antimicrobial Agents and Chemotherapy, 58, 1479-1487.

[Citation: Arif, F., Tahir, T., Suhail, S., Anees, R., Nadeem I, Hafeez, M.M., (2021). Genetic factors associated with mutations of molecular mechanism and drug resistance in Mycobacterium tuberculosis. Biol. Clin. Sci. Res. J., 2021: 72. doi: https://doi.org/10.54112/bcsrj.v2021i1.72] 


\section{(c) (7) (8)}

Open Access This article is licensed under a Creative Commons Attribution 4.0 International License, which permits use, sharing, adaptation, distribution and reproduction in any medium or format, as long as you give appropriate credit to the original author(s) and the source, provide a link to the Creative Commons licence, and indicate if changes were made. The images or other third party material in this article are included in the article's Creative Commons licence, unless indicated otherwise in a credit line to the material. If material is not included in the article's Creative Commons licence and your intended use is not permitted by statutory regulation or exceeds the permitted use, you will need to obtain permission directly from the copyright holder. To view a copy of this licence, visit http://creativecommons.org/licen ses/by/4.0/.

(C) The Author(s) 2021

[Citation: Arif, F., Tahir, T., Suhail, S., Anees, R., Nadeem I, Hafeez, M.M., (2021). Genetic factors associated with mutations of molecular mechanism and drug resistance in Mycobacterium tuberculosis. Biol. Clin. Sci. Res. J., 2021: 72. doi: https://doi.org/10.54112/bcsrj.v2021i1.72] 